\title{
Factors associated with adherence to the Academia da Cidade Program in Recife
}

\section{Fatores associados à adesão ao Programa Academia da Cidade do Recife}

Emmanuelly Correia de Lemos', Letícia Lemos Ayres da Gama Bastos', Geanine Barros da Silva², Carlos Feitosa Luna³, Giselle Campozana Gouveia ${ }^{3}$

\begin{abstract}
This paper aimed to identify factors associated with adherence to the Academia da Cidade Program (ACP) in Recife. It is a cross-sectional study developed in 20 ACP centers, involving 289 users (93.7\% female, $67.1 \%$ aged $30-59$ years) and 244 former users (91.4\% female, $63.5 \%$ aged $30-59$ years) of the program. We used a self-administered questionnaire for data collection. The dependent variable was adherence to the ACP (starting and staying in it for at least three months), and the independent variables were sociodemographic aspects, participation in the ACP, and variables related to the reasons that led participants to start attending the ACP. For data analysis, we used descriptive statistics and binary logistic regression, in which Odds Ratio (OR) was the measure of association. The results of the multivariable analysis revealed that participants aged 30 or older (OR $=7.18 ; 95 \% \mathrm{CI}: 2.57-20.03)$, unemployed $(\mathrm{OR}=1.62 ; 95 \% \mathrm{CI}: 1.01-2.59)$, who had been attending the ACP for 25 months or longer (OR $=7.41$; 95\%CI: 3.80-14.46), whose weekly participation frequency was higher than three days (OR $=7.09$; 95\%CI: 1.81-27.80), and who had started attending the ACP to improve their physical performance (OR $=1.87 ; 95 \% \mathrm{CI}: 1.17-3.00)$ and due to the team's and teacher's confidence and commitment $(\mathrm{OR}=2.78$; 95\%CI: $1.37-5.64)$ were more likely to adhere to the ACP. Therefore, the factors associated with adherence to the ACP were related to sociodemographic characteristics, users' participation in the ACP and reasons that led users to start attending the program.
\end{abstract}

\section{Keywords}

Health Promotion; Physical Activity; Primary Health Care.

\section{Resumo}

O objetivo desta pesquisa foi identificar os fatores associados à adesão ao Programa Academia da Cidade (PAC), no Recife. Estudo transversal, realizado em 20 polos do PAC, e que envolveu 289 usuários (93,7\% do sexo feminino, 67,1\% de 30 a 59 anos de idade) e 244 ex-usuários (91,4\% do sexo feminino de 30 a 59 anos de idade) do programa. Foi utilizado um questionário autoaplicado para coleta de dados. A variável dependente foi adesão ao PAC (iniciar e se manter nele por pelo menos três meses), e as variáveis independentes foram as sociodemográficas, de participação e as relacionadas aos motivos que levaram os participantes a iniciarem no PAC. Para análise dos dados foram utilizadas a estatística descritiva e a regressão logística binária, em que a Odds Ratio (OR) foi a medida de associação. Os resultados da análise multivariável revelaram que os participantes com 30 anos de idade ou mais (OR = 7,18; IC95\%: 2,57-20,03), desempregados $(O R=1,62$; IC95\%: 1,01-2,59), que participavam do PAC por 25 meses ou mais (OR = 7,41; IC95\%: 3,80-14,46) e com uma frequência semanal maior que três dias (OR=7,09; IC95\%: 1,81-27,80), que tinham iniciado no PAC para melhorar seu desempenho físico $(\mathrm{OR}=1,87$; IC95\%: 1,17-3,00) e pela confiança e compromisso da equipe $(O R=2,78$; IC95\%: 1,37-5,64), tiveram mais chances de aderir ao PAC. Conclui-se que os fatores associados à adesão ao PAC foram os relacionados às características sociodemográficas, de participação e aos motivos que levaram os participantes a iniciarem no programa.

\section{Palavras-chave}

Promoção da saúde; Atividade física; Atenção básica à saúde.

\section{Introduction}

In 2002, the Academia da Cidade Program (ACP) was implemented in the city of Recife, state of Pernambuco (Northeastern Brazil). The program is a muni-

\footnotetext{
1 Programa Associado de Pós-Graduação em Educação Física Universidade de Pernambuco/Universidade Federal da Paraíba.

2 Secretaria Municipal de Saúde do Recife. Coordenação de Promoção da Saúde. 3 Núcleo de Saúde Coletiva. Centro de Pesquisas Aggeu Magalhães. Fundação Oswaldo Cruz Pernambuco.
}

cipal health promotion strategy that aims at contributing to promote the health of Recife's population by means of physical activity practice, leisure and guidance for the adoption of healthy habits ${ }^{1}$.

The program's interventions are currently developed at 41 public places - called centers - that were constructed or re-qualified for this purpose. It is important to highlight that the number of centers in 
the city has increased from the end of 2011 onwards, due to a partnership established between Recife's Municipal Health Department and the Cities Department of the State of Pernambuco for the construction of twenty ACP centers in the city.

The ACP professionals also work at 17 Psychosocial Care Centers (PCC) and in more than 60 health or social units, such as family health units, in order to amplify the program's ramification in the network. The interventions developed at the centers happen in the morning, afternoon and evening periods and are conducted by Physical Education Professionals. The population begins to participate in the program by means of spontaneous demand and being referred by the healthcare network ${ }^{1}$.

Although the ACP has been in operation for more than thirteen years, little is known about factors associated with people's adherence to the program; what is known are the reasons that led people to participate in $\mathrm{it}^{2,3}$. The concept of "adherence" is controversial in the literature $e^{4-6}$, but the most used one defines adherence to exercise programs as the act of starting and staying in them.

There is a consensus according to which the variables that contribute to a higher or lower degree of people's participation in physical activity programs can be related to sociodemographic, lifestyle and self-rated health characteristics ${ }^{7-10}$.

In addition, factors like previous participation in physical activity programs, knowledge and beliefs about the benefits of this practice, and aspects like the place of the intervention, the type and intensity of the activity, and the professionals' characteristics and profile also interfere in the population's participation in physical activity interventions ${ }^{10}$.

People's adherence to physical activity promotion programs like the ACP has represented one of the greatest challenges of public health ${ }^{11-13}$. Although there are evidences that point to the health benefits of the regular practice of physical activity $^{14,15}$, the population of many countries still presents insufficient levels of this behavior ${ }^{16,17}$.

The main knowledge gaps about factors that interfere in adherence in community-based interventions for physical activity promotion are related to the characteristics of the offer, accessibility, quality of the spaces and the profile of the professionals involved, as well as to the challenge concerning the implementation of these programs $s^{3,18,19}$. Studies that analyzed adherence to physical activity focused on private fitness centers ${ }^{20,21}$; on the other hand, studies that were carried out in the context of public physical activity promotion programs investigated older adults ${ }^{7,22,23}$.

We would like to highlight the importance of knowing the factors that can influence adherence to programs like the ACP, as this may help to establish strategies that can contribute to greater adherence and to increase their effectiveness ${ }^{24}$. Therefore, this study aimed to identify factors associated with adherence to the ACP in the city of Recife.

\section{Methods}

This descriptive, quantitative, cross-sectional study was conducted at $20 \mathrm{ACP}$ centers. When the study was carried out, there were 21 centers in operation. The only center that was excluded from the study was the one located at Centro Médico Ermirio de Moraes, as only users referred by the center itself attend it.

Centers in all the regions of the city were investigated, located in the following neighborhoods of Recife: Boa Viagem, Brasília Teimosa, Ipsep, Lagoa do Araçá, Ibura, Jardim São Paulo, San Martim, Engenho do Meio, Praça do Poeta, Avenida 
do Forte, Beira Rio, Sítio da Trindade, Morro da Conceição, Jaqueira, Ilha do Leite, Santo Amaro, Coque, Alto do Capitão, Hipódromo and Ilha do Joaneiro.

The study's population was composed of users and former users of the program. Users were considered individuals who, at the moment of data collection, had been participating in the ACP for at least three months. The former users were indicated by one user, and were those who participated in the ACP in the past (2011) for at least three months. We established the period of three months because we believed that, with this participation time, the study's target audience could have experienced more fully the interventions developed by the program, and this would enable them to provide faithful answers about factors related to adherence to the ACP.

The ACP users were randomly selected at the beginning of the activities of each group, in the two periods (morning and evening) of the centers' operation. The former users were selected intentionally by means of the indication of one user who accepted to participate in the study.

Data were collected between October 2011 and January 2012 by four researchers involved in the study. A self-administered questionnaire about reasons that lead people to practice physical activity was used ${ }^{25}$. The variables analyzed in the study were: dependent variable - adherence to the ACP, represented by the user who started and stayed in the program for at least three months (former user/ non-adherent $=0$ and user/adherent $=1)$; independent variables: sex (female $=0$, male $=1$ ), age group (18 to 29 years $=0,30$ to 59 years $=1,60$ years or older $=2$ ), race/skin color (non-white $=0$, white $=1)$, years of schooling ( 1 to 9 years $=0,10$ to 12 years $=1,13$ years or more $=2$ ), marital status ( married $=0$, single $=0$, separated $=2$, widowed $=3$, partner in a stable union $=4$ ), work situation (employed $=0$, unemployed $=1)$, participation time in the ACP $(3$ to 6 months $=0,7$ to 24 months $=1,25$ months or longer $=2$ ), weekly frequency of participation in the ACP (lower than 3 days $=0,3$ days $=1$, higher than 3 days $=2$ ), to adopt a healthy lifestyle (no $=0$, yes $=1)$, likes to exercise $($ no $=0$, yes $=1)$, to increase knowledge in the area of health (no $=0$, yes $=1$ ), to improve physical performance (no $=0$, yes $=1$ ), to improve health (no $=0$, yes $=1$ ), medical advice (no $=0$, yes $=1$ ), to improve self-image (no $=0$, yes $=1)$, to improve self-esteem (no $=0$, yes $=1$ ), to recover from injury (no $=0$, yes $=1)$, to relax/reduce the level of stress (no $=0$, yes $=1$ ), to recover from daily work activities ( $\mathrm{no}=0$, yes $=1$ ), influence of television/ media (no $=0$, yes $=1$ ), time available for the practice (no $=0$, yes $=1)$, period of the year $($ no $=0$, yes $=1)$, program's location $($ no $=0$, yes $=1)$, activities offered by the program (no $=0$, yes $=1$ ), social support given by friends and colleagues ( $\mathrm{no}=$ 0 , yes $=1$ ), to expand the social network (no $=0$, yes $=1$ ), social support given by partner and family (no $=0$, yes $=1$ ), social support given by the team and teacher (no $=0$, yes $=1)$, team's and teacher's confidence and commitment (no $=0$, yes $=$ 1 ), likes challenges ( $\mathrm{no}=0$, yes $=1$ ), to leave home (no $=0$, yes $=1$ ),

The data were keyboarded with double entry in the Epi Info software (version 3.5.3). Afterwards, the validate procedure was performed. For data analysis, the Stata software (version 11.0) was used.

Initially, a descriptive analysis of the data was conducted to characterize the study groups (users and former users) and the chi-square test was applied to compare differences among proportions of the independent variables and among the categories of the dependent variable (former user/non-adherent and user/adherent). To evaluate the crude and adjusted association between the independent variables and the dependent variable, binary logistic regression was used. The 
variables that presented $\mathrm{p}$-value $\leq 0.25^{26}$ in the crude analysis were considered for the multivariable analysis (adjusted). The quality of the final model was evaluated in the following way: (1) comparison of concurrent models (Deviance statistics D-statistics), (2) analysis of multicollinearity (Variance Inflation Factor - VIF) and (3) Hosmer-Lemeshow Test. The residuals of the regression were also evaluated, and influential and leverage points were removed from the final model.

This study was approved by the Ethics Committee of the Centro de Pesquisas Aggeu Magalhães/FIOCRUZ PE under no. 07/2011. All subjects participated voluntarily and signed a consent document.

\section{Results}

Overall, 289 users/adherents and 244 former users/non-adherents participated in the study. In both groups (users/adherents and former users/non-adherents, respectively), it was verified that the majority were female ( $92.7 \%$ and $91.4 \%, \mathrm{p}=0.568$ ), aged 30 to 59 years $(67.1 \%$ and $63.5 \%$, $\mathrm{p}<0.001)$, referred being non-white $(63.7 \%$ and $68.9 \%, \mathrm{p}=0.200)$, had 10 to 12 years of schooling $(55.7 \%$ and $54.1 \%, \mathrm{p}=0.142)$, and were married or lived with partner $(46.0 \%$ and $43.9 \%, \mathrm{p}=0.009)$ - Table 1 .

Concerning participation in the ACP, the majority of users/adherents had been participating for 25 months or longer (50.2\%) and the former users/non-adherents participated in the program during 7 to 24 months $(51.2 \%, \mathrm{p}=0.001)$. Both the users/adherents $(83.4 \%)$ and the non-users/non-adherents $(67.2 \%)$ had a frequency of participation of three days or more per week $(\mathrm{p}=0.001)$ - Table 1 .

Among the eleven most cited reasons by users/adherents and former users/ non-adherents to start attending the ACP, seven were related to interpersonal factors and four were related to the program. Of the reasons related to interpersonal factors, only likes to exercise had a statistically significant difference between the studied groups: $43.3 \%$ for users/adherents and $29.1 \%$ for former users/non-adherents $(p=0.001)$. On the other hand, all the ACP-related reasons had a significant difference between the analyzed groups (users/adherents and former users/ non-adherents, respectively). The reasons were: activities offered by the program (43.6\% and $30.7 \%, \mathrm{p}=0.002)$, social support given by the team and teacher $(42.6 \%$ and $31.1 \%, \mathrm{p}=0.007)$, location of the ACP ( $41.9 \%$ and $30.7 \%, \mathrm{p}=0.008)$, team's and teacher's confidence and commitment (16.6\% and $10.2 \%, \mathrm{p}=0.035)$ - Table 2 .

In the crude analysis, the variables associated $(\mathrm{p}<0.05)$ with adherence to the ACP were age group, marital status, work situation, participation time in the ACP, number of days per week, started attending the program because likes to exercise and likes challenges, because of the activities offered by the program, because of its location, and because of the team's and teacher's confidence, commitment and social support - Tables 3 and 4.

In the adjusted analysis, the following variables remained associated: age group, work situation, participation time in the ACP, number of days per week, and started attending the program because of the team's and teacher's confidence and commitment. Unlike the crude analysis, started attending the program to improve physical performance was also associated. However, other reasons related to the ACP (activities offered by the program, social support given by the team and teacher and the program's location) lost their significance in this analysis, and some remained as variables that adjusted the model. 
TABLE 1 - Distribution of sociodemographic characteristics and characteristics related to users' and former users' participation in the Academia da Cidade Program (ACP), Recife, 2012.

\begin{tabular}{|c|c|c|c|c|c|}
\hline \multirow{2}{*}{ Characterization of participants } & \multicolumn{2}{|c|}{ User $(n=289)$} & \multicolumn{2}{|c|}{ Former user $(n=244)$} & \multirow[b]{2}{*}{ p-value } \\
\hline & $n$ & $\%$ & $n$ & $\%$ & \\
\hline \multicolumn{5}{|l|}{ Sex } & \multirow{3}{*}{0.568} \\
\hline Female & 268 & 92.7 & 223 & 91.4 & \\
\hline Male & 21 & 7.3 & 21 & 8.6 & \\
\hline \multicolumn{5}{|l|}{ Age group (years) } & \multirow{4}{*}{$<0.001$} \\
\hline 18 to 29 & 11 & 3.8 & 48 & 19.7 & \\
\hline 30 to 59 & 194 & 67.1 & 155 & 63.5 & \\
\hline 60 or older & 84 & 29.1 & 41 & 16.8 & \\
\hline \multicolumn{5}{|l|}{ Race/Skin color } & \multirow{4}{*}{0.200} \\
\hline Non-white & 184 & 63.7 & 168 & 68.9 & \\
\hline White & 105 & 36.3 & 76 & 31.1 & \\
\hline \multicolumn{5}{|l|}{ Years of schooling } & \\
\hline 1 to 9 years & 83 & 28.7 & 65 & 26.6 & \multirow{4}{*}{1.42} \\
\hline 10 to 12 years & 161 & 55.7 & 132 & 54.1 & \\
\hline 13 or more & 45 & 15.6 & 47 & 19.3 & \\
\hline \multicolumn{5}{|l|}{ Marital status } & \\
\hline Single & 64 & 22.1 & 89 & 36.5 & \multirow{5}{*}{0.009} \\
\hline Married & 133 & 46.0 & 107 & 43.9 & \\
\hline Separated & 31 & 10.7 & 15 & 6.1 & \\
\hline Widowed & 38 & 13.1 & 18 & 7.4 & \\
\hline Partner in a stable union & 23 & 8.0 & 15 & 6.1 & \\
\hline \multicolumn{5}{|l|}{ Work situation } & \multirow{4}{*}{0.006} \\
\hline Employed & 111 & 38.4 & 123 & 50.4 & \\
\hline Unemployed & 178 & 61.6 & 121 & 49.6 & \\
\hline \multicolumn{5}{|l|}{ Participation time in the ACP } & \\
\hline 3 to 6 months & 44 & 15.2 & 80 & 32.8 & \multirow{4}{*}{0.001} \\
\hline 7 to 24 months & 100 & 34.6 & 125 & 51.2 & \\
\hline 25 months or longer & 145 & 50.2 & 39 & 16.0 & \\
\hline \multicolumn{5}{|c|}{ Number of days in which participates in the ACP (days per week) } & \\
\hline Less than 3 days & 10 & 3.5 & 26 & 10.7 & \multirow{3}{*}{0.001} \\
\hline 3 days & 38 & 13.1 & 54 & 22.1 & \\
\hline More than 3 days & 241 & 83.4 & 164 & 67.2 & \\
\hline
\end{tabular}

Thus, people aged 30 years or older $(\mathrm{OR}=7.18$; 95\%CI: $2.57-20.03)$ who have been participating in the ACP for a period of 25 months or longer $(\mathrm{OR}=7.41$; 95\%CI: 3.80-14.46), with a weekly frequency of participation higher than 3 days $(\mathrm{OR}=7.09$; 95\%CI: 1.81-27.80), were seven times more likely to adhere to the ACP when compared to younger individuals who have been participating in the ACP for up to six months and attend it at least three days per week - Table 5. Individuals who reported being unemployed $(\mathrm{OR}=1.62 ; 95 \% \mathrm{CI}$ : 1.01-2.59) and having started attending the ACP to improve physical performance (OR $=1.87 ; 95 \% \mathrm{CI}: 1.17-3.00)$ were almost two times more likely to adhere to the program. And those who started attending the program because of the team's and teacher' confidence and commitment $(\mathrm{OR}=2.78 ; 95 \% \mathrm{CI}: 1.37-5.64)$ were almost three times more likely to adhere compared to employed individuals and those who started for other reasons - Table 5. This model presented a good quality of adjustment. The VIF values were below 1.41 for all variables and the result of the Hosmer-Lemeshow Test was 0.29 ( $\mathrm{p}=0.05)$. 
TABLE 2 - Distribution of users' and former users' reasons for starting to attend the Academia da Cidade Program (ACP), Recife, 2012.

\begin{tabular}{|c|c|c|c|c|c|}
\hline \multirow{2}{*}{ Reasons for starting to attend the ACP } & \multicolumn{2}{|c|}{ User $(n=289)$} & \multicolumn{2}{|c|}{$\begin{array}{l}\text { Former user } \\
(n=244)\end{array}$} & \multirow[t]{2}{*}{ p-value } \\
\hline & $\mathrm{n}$ & $\%$ & $n$ & $\%$ & \\
\hline To adopt a healthy lifestyle & 259 & 89.6 & 223 & 91.4 & 0.488 \\
\hline To relax/reduce the level of stress & 142 & 49.1 & 108 & 44.3 & 0.262 \\
\hline To improve physical performance & 143 & 49.5 & 102 & 41.8 & 0.077 \\
\hline To improve health & 135 & 46.7 & 109 & 44.7 & 0.638 \\
\hline Activities offered by the program & 126 & 43.6 & 75 & 30.7 & 0.002 \\
\hline $\begin{array}{l}\text { Social support given by the team and } \\
\text { teacher }\end{array}$ & 123 & 42.6 & 76 & 31.1 & 0.007 \\
\hline Likes to exercise & 125 & 43.3 & 71 & 29.1 & 0.001 \\
\hline Program's location & 121 & 41.9 & 75 & 30.7 & 0.008 \\
\hline To improve self-esteem & 105 & 36.3 & 86 & 35.2 & 0.323 \\
\hline Time available for the practice & 61 & 21.1 & 45 & 18.4 & 0.443 \\
\hline $\begin{array}{l}\text { Social support given by friends and } \\
\text { colleagues }\end{array}$ & 52 & 18.0 & 44 & 18.0 & 0.991 \\
\hline Medical advice & 46 & 15.9 & 37 & 15.2 & 0.811 \\
\hline Social support given by partner and family & 46 & 15.9 & 37 & 15.7 & 0.811 \\
\hline $\begin{array}{l}\text { Team's and teacher's confidence and } \\
\text { commitment }\end{array}$ & 48 & 16.6 & 25 & 10.2 & 0.035 \\
\hline To expand the social network & 37 & 12.8 & 31 & 12.7 & 0.973 \\
\hline To improve self-image & 35 & 12.1 & 23 & 9.4 & 0.323 \\
\hline To recover from daily work activities & 25 & 8.7 & 18 & 7.4 & 0.591 \\
\hline To recover from injuries & 11 & 3.8 & 16 & 6.6 & 0.154 \\
\hline To increase knowledge in the area of health & 7 & 2.4 & 8 & 3.3 & 0.553 \\
\hline To leave home & 6 & 2.1 & 6 & 2.5 & 0.767 \\
\hline Likes challenges & 8 & 2.8 & 2 & 0.8 & 0.120 \\
\hline Period of the year & 5 & 1.7 & 3 & 1.2 & 0.443 \\
\hline Influence of television/media & 2 & 0.7 & 5 & 2.0 & 0.191 \\
\hline
\end{tabular}

TABLE 3 - Crude logistic regression analysis to associate sociodemographic and participation characteristics with adherence to the Academia da Cidade Program (ACP), Recife, 2012.

\begin{tabular}{|c|c|c|c|c|c|c|}
\hline \multirow{2}{*}{$\begin{array}{l}\text { Sociodemographic and } \\
\text { participation in the ACP } \\
\text { characteristics }\end{array}$} & \multirow[t]{2}{*}{ Total } & \multicolumn{2}{|c|}{ Adherence } & \multirow[t]{2}{*}{$\mathrm{OR}$} & \multirow[t]{2}{*}{$95 \% \mathrm{Cl}$} & \multirow[t]{2}{*}{ p-value } \\
\hline & & $n$ & $\%$ & & & \\
\hline \multicolumn{7}{|l|}{ Sex } \\
\hline Female & 491 & 268 & 54.6 & 1.00 & - & - \\
\hline Male & 42 & 21 & 50.0 & 0.83 & $0.44-1.56$ & 0.568 \\
\hline \multicolumn{7}{|l|}{ Age group } \\
\hline 18 to 29 & 59 & 11 & 18.6 & 1.00 & - & - \\
\hline 30 to 59 & 349 & 194 & 55.6 & 5.46 & $2-74-10.8$ & $<0.001$ \\
\hline 60 or older & 125 & 84 & 67.2 & 8.94 & $4.20-19.0$ & $<0.001$ \\
\hline \multicolumn{7}{|l|}{ Race/Skin color } \\
\hline Non-white & 352 & 184 & 52.3 & 1.00 & - & - \\
\hline White & 181 & 105 & 58.0 & 0.79 & $0.55-1.13$ & 0.20 \\
\hline
\end{tabular}

Continues... 
... continues.

\begin{tabular}{|c|c|c|c|c|c|c|}
\hline \multirow{2}{*}{$\begin{array}{l}\text { Sociodemographic and } \\
\text { participation in the ACP } \\
\text { characteristics }\end{array}$} & \multirow[t]{2}{*}{ Total } & \multicolumn{2}{|c|}{ Adherence } & \multirow[t]{2}{*}{$\mathrm{OR}$} & \multirow[t]{2}{*}{$95 \% \mathrm{Cl}$} & \multirow[t]{2}{*}{$p$-value } \\
\hline & & $n$ & $\%$ & & & \\
\hline \multicolumn{7}{|l|}{ Years of schooling } \\
\hline 1 to 9 years & 148 & 83 & 56.1 & 1.00 & - & - \\
\hline 10 to 12 years & 293 & 161 & 54.9 & 0.95 & $0.64-1.42$ & 1.42 \\
\hline 13 or more & 92 & 45 & 48.9 & 0.74 & $0.44-1.26$ & - \\
\hline \multicolumn{7}{|l|}{ Marital status } \\
\hline Married & 240 & 133 & 55.4 & 1.00 & - & - \\
\hline Single & 153 & 64 & 41.8 & 0.58 & $0.38-0.87$ & 0.009 \\
\hline Separated & 46 & 31 & 67.4 & 1.66 & $0.85-3.24$ & 0.135 \\
\hline Widowed & 56 & 38 & 67.9 & 1.69 & $0.91-3.14$ & 0.092 \\
\hline Partner in a stable union & 38 & 23 & 60.5 & 1.23 & $0.613-2.48$ & 0.556 \\
\hline \multicolumn{7}{|l|}{ Work situation } \\
\hline Employed & 234 & 111 & 59.5 & 1.00 & - & - \\
\hline Unemployed & 299 & 178 & 47.4 & 1.63 & $0.15-2.30$ & 0.006 \\
\hline \multicolumn{7}{|l|}{ Participation time in the ACP } \\
\hline 3 to 6 months & 124 & 44 & 35.5 & 1.00 & - & - \\
\hline 7 to 24 months & 225 & 100 & 44.4 & 1.45 & $0.93-2.29$ & - \\
\hline 25 months or longer & 184 & 145 & 78.8 & 6.76 & $4.06-11.26$ & $<0.001$ \\
\hline \multicolumn{7}{|c|}{ Number of days in which participates in the ACP } \\
\hline$<3$ days & 36 & 10 & 3.5 & 1.00 & - & - \\
\hline 3 days & 92 & 38 & 13.1 & 1.83 & $0.79-4.23$ & - \\
\hline$>3$ days & 405 & 241 & 83.4 & 3.82 & $1.79-8.14$ & 0.001 \\
\hline
\end{tabular}

TABLE 4 - Crude logistic regression analysis to associate self-reported reasons for starting to attend and adhering to the Academia da Cidade Program (ACP), Recife, 2012.

\begin{tabular}{|c|c|c|c|c|c|c|}
\hline \multirow{2}{*}{$\begin{array}{l}\text { Reasons for starting to attend } \\
\text { the ACP }\end{array}$} & \multirow{2}{*}{ Total } & \multicolumn{2}{|c|}{ Adherence } & \multirow{2}{*}{ OR } & \multirow{2}{*}{$95 \% \mathrm{Cl}$} & \multirow{2}{*}{$p$-value } \\
\hline & & $n$ & $\%$ & & & \\
\hline \multicolumn{7}{|l|}{ To adopt a healthy lifestyle } \\
\hline No & 51 & 30 & 58.8 & 1.00 & - & - \\
\hline Yes & 482 & 259 & 53.7 & 0.81 & $0.45-1.46$ & 0.488 \\
\hline \multicolumn{7}{|l|}{ Likes to exercise } \\
\hline No & 337 & 164 & 48.6 & 1.00 & - & - \\
\hline Yes & 196 & 125 & 63.7 & 1.86 & $1.29-2.67$ & 0.001 \\
\hline \multicolumn{7}{|c|}{ To increase knowledge in the area of health } \\
\hline No & 518 & 282 & 54.4 & 1.00 & - & - \\
\hline Yes & 15 & 7 & 46.7 & 0.732 & $0.26-2.05$ & 0.553 \\
\hline \multicolumn{7}{|l|}{ To improve physical performance } \\
\hline No & 288 & 146 & 50.7 & 1.00 & - & - \\
\hline Yes & 245 & 143 & 58.3 & 1.36 & $0.97-1.92$ & 0.077 \\
\hline \multicolumn{7}{|l|}{ To recover from injuries } \\
\hline No & 506 & 278 & 54.9 & 1.00 & - & - \\
\hline Yes & 27 & 11 & 40.7 & 0.56 & $0.26-1.24$ & 0.154 \\
\hline \multicolumn{7}{|l|}{ To improve health } \\
\hline No & 289 & 154 & 53.3 & 1.00 & - & - \\
\hline Yes & 244 & 135 & 55.3 & 1.09 & $0.77-1.53$ & 0.638 \\
\hline \multicolumn{7}{|l|}{ Medical advice } \\
\hline No & 450 & 243 & 54.0 & 1.00 & - & - \\
\hline
\end{tabular}

Continues... 
... continues.

\begin{tabular}{|c|c|c|c|c|c|c|}
\hline \multirow{2}{*}{$\begin{array}{l}\text { Reasons for starting to attend } \\
\text { the ACP }\end{array}$} & \multirow{2}{*}{ Total } & \multicolumn{2}{|c|}{ Adherence } & \multirow{2}{*}{ OR } & \multirow{2}{*}{$95 \% \mathrm{Cl}$} & \multirow{2}{*}{ p-value } \\
\hline & & $n$ & $\%$ & & & \\
\hline Yes & 83 & 46 & 55.4 & 1.06 & $0.66-1.69$ & 0.811 \\
\hline \multicolumn{7}{|l|}{ To improve self-image } \\
\hline No & 475 & 254 & 53.5 & 1.00 & - & - \\
\hline Yes & 58 & 35 & 60.3 & 1.32 & $0.76-2.30$ & 0.323 \\
\hline \multicolumn{7}{|l|}{ To improve self-esteem } \\
\hline No & 342 & 184 & 53.8 & 1.00 & - & - \\
\hline Yes & 191 & 105 & 55.0 & 1.05 & $0.74-1.49$ & 0.794 \\
\hline \multicolumn{7}{|c|}{ To relax/reduce the level of stress } \\
\hline No & 283 & 147 & 51.9 & 1.00 & - & - \\
\hline Yes & 250 & 142 & 56.8 & 1.22 & $0.86-1.71$ & 0.262 \\
\hline \multicolumn{7}{|c|}{ To recover from daily work activities } \\
\hline No & 490 & 264 & 53.8 & 1.00 & - & - \\
\hline Yes & 43 & 25 & 58.1 & 1.19 & $0.63-2.24$ & 0.591 \\
\hline \multicolumn{7}{|l|}{ Influence of television/media } \\
\hline No & 526 & 287 & 54.6 & 1.00 & - & - \\
\hline Yes & 7 & 2 & 28.6 & 0.33 & $0.06-1.73$ & 0.191 \\
\hline \multicolumn{7}{|l|}{ Time available for the practice } \\
\hline No & 427 & 228 & 53.4 & 1.00 & - & - \\
\hline Yes & 106 & 61 & 57.5 & 1.18 & $0.77-1.82$ & 0.443 \\
\hline \multicolumn{7}{|l|}{ Period of the year } \\
\hline No & 525 & 284 & 54.1 & 1.00 & - & - \\
\hline Yes & 8 & 5 & 62.5 & 1.41 & $0.34-5.98$ & 0.637 \\
\hline \multicolumn{7}{|l|}{ Program's location } \\
\hline No & 337 & 168 & 49.8 & 1.00 & - & - \\
\hline Yes & 196 & 121 & 61.7 & 1.62 & $1.13-2.32$ & 0.008 \\
\hline \multicolumn{7}{|l|}{ Activities offered by the program } \\
\hline No & 332 & 163 & 49.1 & 1.00 & - & - \\
\hline Yes & 201 & 126 & 62.7 & 1.74 & $1.21-2.49$ & 0.002 \\
\hline \multicolumn{7}{|c|}{ Social support given by friends and colleagues } \\
\hline No & 437 & 237 & 54.2 & 1.00 & - & - \\
\hline Yes & 96 & 52 & 54.2 & 0.99 & $0.64-1.55$ & 0.991 \\
\hline \multicolumn{7}{|l|}{ To expand the social network } \\
\hline No & 465 & 252 & 54.2 & 1.00 & - & - \\
\hline Yes & 68 & 37 & 54.4 & 1.01 & $0.61-1.68$ & 0.973 \\
\hline \multicolumn{7}{|c|}{ Social support given by partner and family } \\
\hline No & 450 & 243 & 54.0 & 1.00 & - & - \\
\hline Yes & 83 & 46 & 55.42 & 1.06 & $0.66-1.69$ & 0.811 \\
\hline \multicolumn{7}{|c|}{ Social support given by the team and teacher } \\
\hline No & 334 & 166 & 49.7 & 1.00 & - & - \\
\hline Yes & 199 & 123 & 61.8 & 1.64 & $1.14-2.34$ & 0.007 \\
\hline \multicolumn{7}{|c|}{ Team's and teacher's confidence and commitment } \\
\hline No & 460 & 241 & 52.4 & 1.00 & - & - \\
\hline Yes & 73 & 48 & 65.7 & 1.75 & $1.04-2.93$ & 0.035 \\
\hline Likes challenges & & & & & & \\
\hline No & 523 & 281 & 53.7 & 1.00 & - & - \\
\hline Yes & 10 & 8 & 80.0 & 3.45 & $0.73-16.38$ & 0.120 \\
\hline To leave home & & & & & & \\
\hline No & 521 & 283 & 54.3 & 1.00 & - & - \\
\hline Yes & 12 & 6 & 50.0 & 0.84 & $0.27-2.64$ & 0.767 \\
\hline
\end{tabular}


TABLE 5 - Adjusted logistic regression analysis to associate sociodemographic characteristics, participation characteristics and reasons for starting to attend the program with adherence to the Academia da Cidade Program (ACP), Recife, 2012.

\begin{tabular}{|c|c|c|c|c|c|c|}
\hline Factors associated with adherence to the ACP & OR & $95 \% \mathrm{Cl}$ & $p$-value & $O R^{*}$ & $95 \% \mathrm{Cl}$ & p-value \\
\hline \multicolumn{7}{|l|}{ Age group } \\
\hline 18 to 29 & 1.00 & - & - & 1.00 & - & - \\
\hline 30 to 59 & 5.46 & $2.74-10.8$ & $<0.001$ & 7.18 & $2.57-20.03$ & $<0.001$ \\
\hline 60 or older & 8.94 & $4.20-19.0$ & - & 6.22 & $2.00-19.45$ & 0.002 \\
\hline \multicolumn{7}{|l|}{ Work situation } \\
\hline Employed & 1.00 & - & - & 1.00 & - & - \\
\hline Unemployed & 1.63 & $0.15-2.30$ & 0.006 & 1.62 & $1.01-2.59$ & 0.042 \\
\hline \multicolumn{7}{|l|}{ Participation time in the ACP } \\
\hline 3 to 6 months & 1.00 & - & - & 1.00 & - & - \\
\hline 7 to 24 months & 1.45 & $0.93-2.29$ & - & 1.08 & $0.61-1.91$ & - \\
\hline 25 months or longer & 6.76 & $4.06-11.26$ & $<0.001$ & 7.41 & $3.80-14.46$ & $<0.001$ \\
\hline \multicolumn{7}{|l|}{ Number of days in which participates in the ACP } \\
\hline$<3$ days & 1.00 & - & - & 1.00 & - & - \\
\hline 3 days & 1.83 & $0.79-4.23$ & - & 3.69 & $0.87-15.51$ & - \\
\hline$>3$ days & 3.82 & $1.79-4.23$ & - & 7.09 & $1.81-27.80$ & 0.005 \\
\hline \multicolumn{3}{|c|}{ Reason to adhere - To improve physical performance } & 0.001 & & & \\
\hline No & 1.00 & - & - & 1.00 & - & - \\
\hline Yes & 1.36 & $0.97-1.92$ & 0.07 & 1.87 & $1.17-3.00$ & 0.009 \\
\hline \multicolumn{7}{|c|}{ Reason to adhere - Team's and teacher's confidence and commitment } \\
\hline No & 1.00 & - & - & 1.00 & - & - \\
\hline Yes & 1.75 & $1.04-2.93$ & 0.035 & 2.78 & $1.37-5.64$ & 0.004 \\
\hline
\end{tabular}

* Adjusted by race/skin color, marital status, having started to attend the ACP for the following reasons: likes to exercise, to recover from injuries, program's location and activities offered by the program.

\section{Discussion}

The results of the present study revealed that the participants who were more likely to adhere to the ACP were adults who were unemployed and who started attending the ACP motivated to improve their physical performance and because of the team's and teacher's confidence and commitment. Likewise, users who had been participating in the ACP for more than one year and attended it on the majority of the weekdays in which the program is in operation were also more likely to adhere.

A higher adherence of adults aged 30 years or older was observed in the present study. A similar result was found in the study carried out by Andreotti and Oku$\mathrm{ma}^{11}$, indicating that physical activity practice can be more experienced among adults, as their motivation to pursue a healthy behavior can be based on the search for health. On the other hand, reaching the younger public, which is also an objective of the $\mathrm{ACP}^{1}$, is one of the challenges posed to the program. Thus, new strategies must be developed and/or strengthened to contribute to the adherence of this population.

Being unemployed was also associated with being more likely to adhere to the ACP. Having a flexible schedule and the possibility of committing to the regular practice of physical exercises can favor these people's adherence to the ACP. This 
population's profile should also be considered. Being unemployed can be related to low and middle income, and also to the development of domestic activities, as the majority were women, and many of them could be already retired.

Some of the findings of the present study were similar to the results of a study conducted by Costa, Bottcher and Kokubun ${ }^{27}$ : participants who had been attending the program with a weekly frequency of three days or more for 25 months or longer. These authors argued that the higher the participation time, the more likely the participants are to stay in the programs. Therefore, to meet the expectations of older and more assiduous users and, likewise, guarantee the adherence of new participants to the ACP, routines for planning and monitoring that fit this reality need to be established.

The participants who started attending the ACP with the objective of improving their physical performance and due to the team's and teacher's confidence and commitment were the ones who were most likely to adhere to the program. In a study carried out by Feitosa ${ }^{2}$ with ACP users in 2015, the majority indicated the relationship with the teachers and their competence as strong points for them to stay in the program. A systematic review conducted by Martins ${ }^{28}$ found that, to guarantee quality in the health services, one of the necessary aspects is the good professional-user relationship.

In the present study, enjoying physical exercise and recovering from injuries were reasons to adhere to the ACP related to interpersonal aspects. This was reported by another study ${ }^{11}$ that found that adherence was related to participants' individual perceptions and expectations. Therefore, perceptions and expectations must be taken into account in the program's planning activities.

The program's location was one of the reasons to adhere to the ACP. This indicates that having a program decentralized in the territory contributes to people's adherence, which strengthens the importance of re-qualifying and valuing public spaces ${ }^{2,11}$.

Evidences about the physical environment's influence on exercise adherence reveal that access to the facilities serves as a visual stimulus and reduces physical and psychological barriers associated with exercising, as the fact that the place for the practice is nearby reduces the person's travel time. Thus, it is a variable that interferes in the person's choice to exercise ${ }^{29,30}$.

In this study, the activities offered by the ACP represented an important factor for people's adherence to the ACP. In the studies conducted by Feitosa ${ }^{2}$ and Hal$\mathrm{lal}^{3}$, the authors observed that users show a high degree of satisfaction regarding these activities, which contributes to their adherence to the program.

Knowing the factors associated with adherence to physical activity promotion programs is fundamental, as it enables to adapt the programs to users' expectations, and allows to mobilize adequate resources to the population's specific needs, increasing adherence itself, satisfaction and programs' effectivity ${ }^{3}$.

The results found in this study enhanced knowledge in the field of study of adherence to physical activity promotion programs, highlighting that the factors that contribute to people's adherence to these programs are related to personal characteristics and also to the program's characteristics. Therefore, the professionals and managers of these programs must attempt to investigate these factors and, then, define strategies that are able to identify the aspects that contribute positively to adherence and revise the elements that produce a negative influence on people's participation in the programs.

Some limitations should be considered in the interpretation of the findings of this study: the cross-sectional design, which does not allow to consider, with a high 
degree of certainty, whether the relationship between exposure (sociodemographic and participation aspects and reasons for starting to attend the ACP) and the outcome (adherence to the ACP) is causal or not; the selection bias, as users/adherents were randomly selected and former users/non-adherents were selected in an intentional way; and the memory bias: as a self-administered questionnaire was used, this may have overestimated some results, in the case of users/adherents who remembered more easily the exposure to ACP-related aspects, or underestimated the results, in the case of former users/non-adherents, who may not have mentioned some exposure because they were no longer participating in the program.

We believe that further research is needed in order to analyze factors related to adherence to public programs of physical activity promotion. Such research should include other investigation techniques, such as the focus group, to enable a deeper understanding of this field of knowledge.

We conclude that the factors associated with adherence to the ACP were related to sociodemographic and participation characteristics and to reasons that led the participants to start attending the program. These results can help the ACP's professionals and managers to establish and improve practical strategies to increase people's adherence to the program.

\section{Acknowledgments}

We would like to thank all the individuals who contributed, directly or indirectly, to the conduction of this research. The research was not financed by any fostering agency. It was financed by the authors themselves.

\section{Authors' contributions}

All the authors participated in the conception of the project or in data analysis and interpretation, in the article's writing and in the critical revision of the intellectual content, and also in the final approval of the version to be published.

\section{References}

1. Lemos EC, Gouveia GC, Luna CF. Programa Academia da Cidade: A experiência de Recife [Academia da Cidade Program: Recife's experience]. In: Gurgel IGD, Medeiros KR, Aragão AV, Santana, RM (eds). Gestão em Saúde Pública: contribuições para a política [Public Health Management: Contributions to the policy]. Recife: Editora UFPE; 2014. p. 140-53.

2. Feitosa, WN. Programas de promoção da atividade física: estudo de caso acerca da implementação do Programa Academia da Cidade (PAC) em Recife entre 2002 e 2014 [Physical activity promotion programs: A case study about the implementation of the Academia da Cidade Program (ACP) in Recife between 2002 and 2014] [tese de doutorado]. Recife: Centro de Pesquisas Aggeu Magalhães; 2015.

3. Hallal PC, Tenório MM, Tassitano RM, Reis RS, Carvalho YM, Cruz DA, et al. Avaliação do programa de promoção da atividade física Academia da Cidade de Recife, Pernambuco, Brasil: percepções de usuários e não-usuários. [Evaluation of the Academia da Cidade program to promote physical activity in Recife, Pernambuco State, Brazil: perceptions of users and non-users] Cad. Saúde Pública. 2010; 26(1):70-8.

4. Hardage J, Peel C, Morris D, Graham C, Brown CJ, Foushee R, Braswell J. Adherence to exercise scale for older patients (AESOP): A measure for predicting exercise adherence in older adults after discharge from home health physical therapy. J Geriat Phys Ther. 2007; 30: 69-70.

5. Pisters MF, Veenhof C, Schellevis FG, Twisk JW, Dekker J, De Bakker DH. Exercise adherence improving long term patient outcome in patients with osteoarthritis of the hip and/or knee. Arthr Care Res. 2010; 62(8): 1087-94.

6. Huberty JL, Vener J, Waltman Ott C, Twiss J, Gross G, Mcguire R, Dwyer A. Development of an instrument to measure adherence to strength training in postmenopausal breast cancer survivors. Oncol Nurs Fórum. 2009; 36(5): 266-73. 
7. Picorelli AM, Pereira DS, Felício, DC, Gomes DA, Dias RC, Pereira, LS. Adesão de idosas a um programa de exercícios domiciliares pós-treinamento ambulatorial. [Older women's adherence to a home exercise program after outpatient training] Fisioter. Pesqui. 2015: 22(3): 291-308.

8. Bauman AE, Reis RS, Sallis JF, Wells JC, Loos RJ, Martin BW. Correlates of physical activity: why are some people physically active and others not? Lancet. 2012;380(9838):258-71.

9. Sallis R, Franklin B, Joy L, Ross R, Sabgir D, Stone J. Strategies for promoting physical activity in clinical practice. Prog Cardiovasc Dis. 2015;57(4):375-86.

10. Andreotti MC, Okuma SS. Perfil sociodemográfico e de adesão inicial de idosos ingressantes em um programa de Educação Física. [Sociodemographic and initial adherence profile of older adults newly attending a Physical Education program] Rev. Paul. Educ. Fís. 2003;17(2):142-53.

11. Lovato N, Loch M, Gonzalez A, Lopes M. Assiduidade a programas de atividade física oferecidos por Unidades Básicas de Saúde: o discurso de participantes muito e pouco assíduos. [Regular attendance in physical activity programs offered by Primary Care Units: The discourse of regular and non-regular participants] Rev Bras Ativ Fis Saúde. 2015; 20(2):184-92.

12. Silvia IC, Knuth AG, Mielke GI, Azevedo MR, Gonçalves H, Hallal PC. Trends in leisure-time physical activity in a southern Brazilian city: 2003-2010. J Phys Act Health. 2014;11(7):1313-7.

13. Rech CR, Reis RS, Hino AA, Rodrihuez-Anez CR, Fermino RC, Gonçalves PB, et al. Neighborhood safety and physical inactivity in adults from Curitiba, Brazil. Int J Behav Nutr Phys Act. 2012;9/72: 1-7.

14. Kohl HW, Craig CL, Lambert EV, Inoue S, Alkandari Jr, Leetongin G, et al. The pandemic of physical inactivity: global action for public health. Lancet. 2012;380(9838):294-305.

15. Lee IM, Shiroma EJ, Lobelo F, Puska P, Blair SN, Katzmarzyk PT. Effect of physical inactivity on major non-communicable diseases worldwide: an analysis of burden of disease and life expectancy. Lancet. 2012;380(9838):219-29.

16. Barufaldi LA, Abreu GA, Coutinho ESF, Bloch KV. Meta-analysis of the prevalence of physical inactivity among Brazilian adolescents. Cad. Saúde Pública. 2012; 28(6):1019-32.

17. Hallal PC, Andersen LB, Bull FC, Guthold R, Haskell W, Ekelund U. Global physical activity levels: surveillance progress, pitfalls and prospects. Lancet. 2012; 380(9838): 247-57.

18. Hoehner CM, Soares J, Perez DP, Ribeiro IC, Joshu CE, Pratt M, et al. Physical activity interventions in Latin America: a systematic review. Am J Prev Med. 2008; 34(3):224-33.

19. Hoehner, CM, Ribeiro IC, Parra DC, Reis, RS, Azevedo MR, Hino, A, et al. Physical activity interventions in Latin America: expanding and classifying the evidence. Am J Prev Med. 2013; 44(3):31-40.

20. Souza JCC, Oliveira DC, Espírito-Santo GE. Percepções e motivações acerca da prática de musculação de uma academia de ginástica da baixada fluminense. [Perceptions and motivations about the weight training practice of a fitness club located in the Baixada Fluminense] Corpus et Scientia. 2012; 8(2):66-77.

21. Liz CM. Motivação para a prática de musculação de aderentes e desistentes de academias [Motivation to practice weight training among adherents and dropouts in fitness centers] [dissertação de mestrado]. Santa Catarina: Universidade do Estado de Santa Catarina (UDESC); 2011.

22. Nascimento MC, Silva OP, Saggioratto ML, Vargas KCB, Schopf K, Klunk J. O desafio da adesão aos exercícios físicos em grupo de idosos em Palmitos/SC: motivos para a prática e para a desistência [The challenge of exercise adherence in a group of older adults in Palmitos, state of Santa Catarina: Reasons for practicing and for dropping out]. Rev Bras Ativ Fís Saúde. 2010; 15(3):140-4.

23. Rocha SV, Carneiro LRV, Júnior LOS. Motivos para a prática de atividade física entre idosos no município de Itabuna - BA [Reasons for practicing physical activity among older adults in the city of Itabuna - state of Bahia]. Rev. APS. 2011; 14(3):276-82.

24. Martin KA, Sinden AR. Who will stay and who will go? A review of older adults adherence to randomized controlled trials of exercise. J Aging Phys Act. 2001; 9(2):91-114.

25. Freitas CM, Santiago MS, Viana AT, Leão AC, Freyre C. Aspectos motivacionais que influenciam a adesão e manutenção de idosos a programas de exercícios físicos [Motivational aspects that influence older adults adhering and staying in physical exercise programs]. Rev. Bras. Cineantropom. Desempenho Hum. 2007;9(1):92-100. 
26. Hosmer Jr, David W, Lemeshow S. Applied logistic regression. John Wiley \& Sons, 2004.

27. Costa BV, Bottcher LB, Kokubun E. Aderência a um programa de atividade física e fatores associados [Adherence to a physical activity program and associated factors]. Motriz. 2009;15(1):25-36.

28. Martins LV. Avaliação da qualidade nos serviços públicos de saúde com base na percepção dos usuários e dos profissionais [Quality evaluation in public health services based on users' and professionals' perception]. RFO. 2014; 19(2): 151-8.

29. Sallis JF, Hovell MF, Hofstetter CR, Elder JP, Hackle M, Caspersen CJ, et al. Distance between homes and exercise facilities related to frequency of exercise among San Diego residents. Public Health Rep. 1990; 105(2):179-85.

30. Sallis JF, Prochaska JJ, Taylor WC. A review of correlates of physical activity of children and adolescents. Med Sci Sports Exerc. 2000; 32(5):963-75.

CORRESPONDING

AUTHOR

EMMANUELLY CORREIA DE LEMOS

emmanuellylemos@gmail.com
Rua Falcão, n 22, Ouro Preto, Olinda,

Pernambuco. CEP: 53370-101.

Telephone: +55 (81) 997190294
RECEIVED 30/11/2015

REVISED 23/02/2016

APPROVED 29/05/2016 